\title{
Kompetensi, Pembinaan Karier dan Kinerja Auditor di Inspektorat Jenderal dan Perbendaharaan Instansi Kementerian Pertahanan
}

\author{
Budi Hardiyatno ${ }^{1}$
}

${ }^{1}$ Universitas Pancasila, Jl. Srengseng Sawah, Jagakarsa, Jakarta Selatan 12640

\section{N F O A R T I K E L}

JEL Classification:

$H 83$

M12

Keywords:

audititors' competence,

auditors' career development,

auditors' performance

\section{A B S T R A C T}

Corruption in the government lead to questions about the performance of government auditors. General Inspectorate and the treasury ministry of defense agencies tasked with monitoring, controlling and monitoring the implementation of activities in the defense ministry. This study aims to investigate the influence of competence and career development on auditor performance. Based on the testing of 87 auditors obtained empirical evidence that the competence and career development affect the performance of the auditor. Future research can develop a model by adding other variables.

\section{A B S S T R R A K}

Perilaku korupsi di pemerintahan menimbulkan pertanyaan tentang kinerja auditor pemerintah. inspektorat jenderal dan perbendaharaan instansi kementerian pertahanan bertugas untuk melakukan pengawasan, pengendalian dan pemantauan pelaksanaan kegiatan di lingkungan kementerian pertahanan. Penelitian ini bertujuan untuk menginvestigasi pengaruh kompetensi dan pembinaaan karir terhadap kinerja auditor. Berdasarkan pengujian pada 87 auditor diperoleh bukti empiris bahwa kompetensi dan pembinaan karir mempengaruhi kinerja auditor. Penelitian mendatang dapat mengembangkan model dengan menambahkan variabel lain.

\section{Pendahuluan}

Sejak awal reformasi, tuntutan masyarakatakan penyelenggaraan pemerintahan yang bersih, transparan dan bebas dari korupsi, kolusidannepotisme $(\mathrm{KKN})$ semakinmeningkat. Kondisi ini mendorong pemerintah dan DPR untuk segera melakukan reformasi terhadap berbagai peraturan perundang-undangan. Dalam bidang keuangan, reformasi dilakukan dengan dikeluarkannya undang-undang keuangan negara, perbendaharaan dan tentang pemeriksaan pengelolaan dan tanggungjawab keuangan negara. Pada penjelasan UUD

*Email Korespondensi: ${ }^{1}$ roro_kumis@gmail.com 
1945 tentang Sistem Pemerintahan Negara yaitu pada Bab VIIIA pasal 23E sampai $23 \mathrm{G}$ menerangkan bahwa perlunya dilaksanakan pengawasan dan pemeriksaan dalam pengelolaan dan pertanggungjawaban keuangan yang dilaksanakan oleh Badan Pemeriksaan Keuangan (BPK) dimana hasil pemeriksaannya diserahkan kepada Dewan Perwakilan Rakyat (DPR), disamping itu untuk kegiatan Badan Pemeriksaan Keuangan (BPK) diatur dengan undang-undang tersendiri yaitu UndangUndang RI nomor 15 tahun 2004.

Pemerintah mengeluarkan peraturan yang mengharuskan adanya badan pengawasan dan pemeriksaan sesuai Peraturan Presiden Republik Indonesia Nomor 9 Tahun 2005 Tentang Kedudukan, Tugas, Fungsi,Susunan Organisasi, Dan Tata Kerja Kementerian Negara Republik Indonesia yaitu pada pasal 78 - pasal 81 dan Peraturan Presiden Republik Indonesia Nomor 47 Tahun 2009 Tentang Pembentukan Dan Organisasi Kementerian Negara pasal 27 ayat (2) d yaitu keharusan dibentuknya lembaga Inspektorat Jenderal sebagai badan pengawas pada setiap Kementerian dan pasal 37 ayat (1) dimana Inspektorat Jenderal berada dibawah dan bertanggungjawab kepada menterinya masingmasing serta Pasal 38 Inspektorat Jenderal mempunyai tugas melaksanakan pengawasan intern di lingkungan Kementerian dipertegas lagi dengan Peraturan Presiden Republik Indonesia Nomor 24 Tahun 2010 Tentang Kedudukan, Tugas, Dan Fungsi Kementerian Negara Serta Susunan Organisasi, Tugas, Dan Fungsi Eselon I Kementerian Negara yaitu pada pasal 121 (g) dan pasal 133 - pasal 134. Sedangkan Menteri Pendayagunaan Aparatur Negara (Menpan) sendiri untuk mengatur kompetensi, pembinaan dan standar Auditor di lingkungan pemerintah juga mengeluarkan aturan yaitu Peraturan Menteri Pendayagunaan Aparatur Negara nomor PER/220/M.PAN/7/2008 tanggal 4 Juli 2008 tentang Jabatan Fungional Auditot dan Angka Kredit. Untuk mewadahi lembaga Inspektorat Jenderal di Kementerian Pertahanan maka dikeluarkan Peraturan Menteri Pertahanan Republik Indonesia nomor
21 Tahun 2010 tentang Sistem Pengendalian Intern Pemerintah Di Lingkungan Kementerian Pertahanan dan Tentara Nasional Indonesia. Di Inspektorat yang jadikan tempat penelitian, terhadap kinerja auditornya masih sering ditemukan temuan yang berulang serta masih ada internal auditnya yang belum sepenuhnya memahami aturan/kreteria yang dijadikan dasar dalam pemeriksaan penyebabnya hal tersebut diantarnya adalah kompetensi dan pembinaan karier termasuk dalam rekrutmen pengawai inspektorat itu sendiri sehingga profesional hasil auditnya meragukan maupun lemahnya penerapan Sistem Pengendalian Intern (SPI) dan Sistem Akuntabilitas Instansi di lingkungan Satuan Kerja tersebut. Sedangkan Sawyer Lawrence B. dkk, (2006, 542-544) juga menyatakan bahwa kompetensi dan pembinaan/ pengembanganjenjangauditor sangatdiperlukan untuk meningkatkan kinerja auditor dan hasil kinerjanya dapat dipertanggungjawabkan dan profesional.

Pelaksanakan kegiatan pengawasan dan pemeriksaan Inspektorat Jenderal Dan Perbendaharaan Instansi Kementerian Pertahanan mengacu pada Undang-Undang maupun Peraturan yang berlaku tentang Sistem Pengendalian Intern di Lingkungan Kementerian dengan berdasarkan Surat Keputusan Panglima TNI nomor Skep/221/VI/2006 tanggal 14 Juni 2006 tentang Petunjuk Dasar Pengawasan Dan Pemeriksaan Tentara Nasional Indonesia dan Surat Keputusan Panglima TNI nomor Skep/25/ I/2013 tanggal 17 Januari 2013 tentang Buku Petunjuk Induk Pengawasan Dan Pemeriksaan Tentara Nasional Indonesia.

Selain itu, di bidang hukum dikeluarkan undang-undang tentang penyelenggaraan negara yang bersih dan bebas KKN, serta undangundang tentang Komisi Pemberantasan Tindak Pidana Korupsi (KPK). Keseluruhan peraturan perundang-undangan tersebut dikeluarkan untuk mewujudkan tuntutan masyarakat akan terselenggaranya pemerintahan yang bersih, taat pada aturan perundang-undangan dan dapat mempertanggungjawabkan pelaksanaan pemerintahan melalui suatu sistem akuntabilitas 
kinerja instansi. Aparat Pengawasan Intern Pemerintah (APIP) memegang peran penting dalam meyakinkan masyarakat bahwa penyelenggaraan dan pertanggungjawaban keuangan pemerintah telah dilaksanakan sesuai harapan, kondisi ini berlaku di setiap unsur pemerintahan termasuk di tubuh instansi Kementerian Pertahanan. Inspektorat Jenderal dan Perbendaharaan (Itjen) instansi Kementerian Pertahanan selaku badan pengawas dan pemeriksa belum melaksanakan perannya secara optimal dalam mewujudkan efektifitas kinerja aparat pemeriksa (Auditor) karena faktor kompetensi dan pembinaan karier belum mendapat perhatian sepenuhnya. Kelemahan-kelemahan lain adalah minimnya perhatian dan keseriusan para pimpinan Satuan Kerja (Satker) dalam menindaklanjuti hasil temuan dan lemahnya penerapan/sanksi hukum yang harus dijatuhkan. Selain itu dalam melaksanakan perannya, Itjen instansi Kementerian Pertahanan masih dihadapkan pada beberapa keterbatasan dan kelemahan ditinjau dari Sistem Pengendalian Intern, pola penyelenggaraan pengawasan dan pemeriksaan, prosedur dan teknik audit, sumber daya manusia yang kurang profesional, rekrutmen personil auditor tidak berdasarkan keahlian tetapi hanya berdasarkan Surat Perintah, sarana dan prasarana serta peranti lunak serta dasar hukum yang digunakan belum sepenuhnya sesuai dengan kebutuhan untuk pelaksanaan kegiatan pemeriksaan. Itjen instansi Kementerian Pertahanan selaku Aparat Pengawas Internal Pemerintah (APIP) di tubuh instansi Kementerian Pertahanan perlu meningkatkan perannya agar dalam melaksanakan kegiatan pemeriksaan dilaksanakan secara profesional.

\section{Telaah Teori dan Pengembangan} Hipotesis

\subsection{Teori Agency}

Teori agensi merupakan konsep yang menjelaskan hubungan kontraktual antara principals dan agents. Pihak principals adalah pihak yang memberikan mandat kepada pihak lain, yaitu agent, untuk melakukan semua kegiatan atas nama principals dalam kapasitasnya sebagai pengambil keputusan (Jensen dan Smith, 1984). Pengawasan atau monitoring yang dilakukan oleh pihak independen memerlukan biaya atau monitoring cost dalam bentuk biaya audit, yang merupakan salah satu dari agency cost (Jensen dan Meckling, 1976). Uraian tersebut diatas memberi makna bahwa auditor merupakan pihak yang dianggap dapat menjembatani kepentingan pihak pemegang saham (principal) dengan pihak manajer (agent) dalam mengelola keuangan perusahaan termasuk menilai kelayakan strategi manajemen dalam upaya untuk mengatasi kesulitan keuangan perusahaan.

Menurut Anthony dan Govindarajan (2005), teori agensi adalah hubungan atau kontrak antara principal dan agent. Teori agensi memiliki asumsi bahwa tiap-tiap individu semata-mata termotivasi oleh kepentingan dirinya sendiri sehingga menimbulkan konflik kepentingan antara principal dan agent. Dari teori ini dapat disimpulkan bahwa professional internal audit sangat berhubungan erat dengan perusahaan/ organisasi termasuk kinerja auditor itu sendiri.

Teori Manajemen Sumber Daya Manusia (MSDM) menurut Gomes (2002:3) adalah: Suatu gerakan pengakuan terhadap pentingnya unsur manusia sebagai sumber daya yang cukup potensial yang perlu dikembangkan sedemikian rupa sehingga mampu memberikan kontribusi yang maksimal bagi organisasi dan bagipengembangan dirinya. Sedangkanmenurut Teori A. Maslow (1943) tentang motivasi yaitu secara mutlak menunjukkan perwujudan diri sebagai pemenuhan (pemuasan) kebutuhan yang bercirikan pertumbuhan dan pengembangan individu. Perilaku yang ditimbulkannya dapat dimotivasikan oleh manajer dan diarahkan sebagai subjek-subjek yang berperan. Dorongan yang dirangsang ataupun tidak, harus tumbuh sebagai subjek yang memenuhi kebutuhannya masing-masing yang harus dicapainya dan sekaligus selaku subjek yang mencapai hasil untuk sasaran-sasaran organisasi 


\subsection{Pengendalian Internal COSO}

COSO, The Committee of Supporting Organizations of the Treadway Commission SAS juga definisikan pengendalian internal (AI. Haryono Jusup, 2001, hal : 252) adalah suatu proses yang dipengaruhi oleh dewan komisaris dan personil satuan usaha lainnya, yang dirancang untuk mendapatkan keyakinan memadai tentang pencapaian tujuan dalam halhal :

- Keandalan pelaporan keuangan

- Kesesuaian dengan perundang-undangan dan peraturan yang berlaku

- Efektifitas dan efisiensi operasi.

Lima komponen yang saling terkait dari pernyataan COSO /Committee of Sponsoring Organization (1992) adalah sebagai berikut :

\section{1) Lingkungan Pengendalian}

Lingkungan Pengendalian mempengaruhi suasana suatu organisasi, mempengaruhi kesadaran tentang pengendalian pegawai. Yang merupakan landasan dari komponen pengendali lainnya adalah dengan menciptakankan disiplin dan struktur. Lingkungan

a) Integritas dan nilai etika b) Komitmen terhadap kompetensi c) Komisaris dan Komite Audit yang aktif dan efektif d) Filosofi manajemen dan gaya operasional e) Struktur Organisasi f) Pemberian wewenang dan tanggung jawab g) Kebijakan dan praktik SDM

\section{2) Perhitungan Risiko}

Perhitungan Risiko untuk tujuan pelaporan keuangan merupakan identifikasi, analisis dan pengelolaan risiko perusahaan yang disajikan secara wajar sesuai dengan prinsip akuntansi berlaku umum. Perhitungan

Risiko:
a) Penetapan Tujuan Tingkat Entitas
b) Penentuan Tujuan Tingkat Aktivitas
c) Identifikasi dan analisa risiko
d) Pengelolaan perubahan

\section{3) Aktifitas Pengendalian}

Aktivitas Pengendalian merupakan kebijakan dan prosedur yang memberikan keyakinan bahwa perintah manajemen telah dilaksanakan dan risiko yang telah dinilai ditangani sebagaimana mestinya. Aktivitas Pengendalian:

a) Keberadaan kebijakan dan prosedur yang tepat

b ) $\mathrm{P}$ e 1 a $\mathrm{k}$ s a $\mathrm{n}$ a $\mathrm{a}$ n kebijakan dan prosedur yang tepat Aktivitas pengendalian terdiri dari kebijakan dan prosedur yang merasakan bahwa diperlukan tindakan untuk meredam risiko dalam upaya pencapaian tujuan perusahaan secara umum. Aktivitas pengendalian dapat dijelaskan sebagai berikut:

(1) Adequate Separation of Duties (Pemisahan Tugas yang Cukup) Pengendalian internal yang baik menetapkan bahwa tidak ada pegawai yang diberikan terlalu banyak tanggung jawab sehingga perlu adanya pemisahan tugas. Beberapa pedoman umum dalam pemisahan tugas untuk mencegah salah saji, baik yang disengaja maupun yang tidak disengaja, yaitu :

(a) Pemisahan fungsi pemegang aktiva dari fungsi akuntansi (b) Pemisahan otorisasi transaksi dari pemegang aktiva yang bersangkutan (c) Pemisahan tanggung jawab operasional dari pembukuan (d) Pemisahan tugas dalam EDP

(2) Proper Authorization of Transaction and Activities (Otorisasi yang Pantas atas Transaksi) Otorisasi dapat berbentuk umum dan khusus. Otorisasi umum berarti bahwa manajemen menyusun kebijakan bagi organisasi untuk 
ditaati. Sedangkan otorisasi khusus dilakukan terhadap transaksi individual. Misalnya, manajemen menentukan kebijakan otorisasi untuk pembelian aktiva berdasarkan jumlah tertentu yang sudah ditetapkan, ini adalah otorisasi umum. Bila jumlah pembelian melebihi yang ditetapkan, maka harus diotorisasi dulu oleh dewan komisaris, ini adalah otorisasi khusus.

(3) Adequate Document and Record (DokumendanCatatanyangMemadai) Dokumen dan catatan adalah objek fisik dimana transaksi dimasukkan dandiikhtisarkan. Dokumen berfungsi sebagai pengantar informasi ke seluruh bagian organisasi. Dokumen harus memadai untuk memberikan keyakinan memadai bahwa seluruh aktiva dikendalikan dengan pantas dan seluruh transaksi dicatat dengan benar. Beberapa prinsip tertentu yang relevan menandai perancangan dan penggunaan yang tepat atas dokumen dan catatan.

Dokumen dan catatan hendaknya :

a) Diberi nomor untuk mencegah terjadinya dokumen yang hilang dan membantu menelusurinya bila diperlukan.

b) Dibuat pada saat yang sama ketikaterjadinya transaksi atau segera sesudahnya.

c) Cukup sederhana agar mudah dimengerti.

d) Dirancangkan untuk berbagai kegunaan (bila mungkin) untuk mengurangi jumlah formulir yang harus dibuat.

e) Dirancang sedemikian rupa untuk memungkinkan penyajian yang benar.
Pengendalian yang erat berkaitan dengan dokumen dan catatan adalah bagan perkiraan yang mengklasifikasikan transaksi ke dalam perkiraan neraca dan laba rugi. Bagan perkiraan merupakan pengendalian yang penting karena memberikan kerangka kerja untuk menentukan informasi yang disajikan kepada manajemen lain dari laporan keuangan. Prosedur untuk pencatatan secara tepat harus disesuaikan dalam sistem manual untuk mendorong penerapan yang konsisten. Sistem manual harus menyediakan informasi yang cukup untuk membantu pencatatan dan mempertahankan informasi yang tepat atas transaksi.

(4) Physical Check on Performance (Pengendalian Fisik atas Aktiva dan Catatan) Jenis perlindungan untuk mengamankan aktiva dan catatan yang paling utama adalah penggunaan tindakan pencegahan secara fisik. Contohnya, penggunaan gudang persediaan untuk melindungi dari kemungkinan terjadinya pencurian.

(5) Independen Check on Performance (Pengecekan Independen atas Pelaksanaan) Kategori terakhir prosedur pengendalian adalah penelaahan yang hati-hati dan berkesimbangan atas keempat prosedur yang lain, yang sering disebut sebagai pengecekan independen atau verifikasi intern. Kebutuhan pengecekan secara independen meningkat karena pengendalian internal cenderung berubah setiap saat jika tidak terdapat mekanisme penelaahan yang sering. Contohnya pegawai mungkin lupa atau sengaja tidak mengikuti prosedur jika tidak ada orang yang meninjau 
atau mengawasi pelaksanaanya.

\section{4) Informasi dan Komunikasi}

Informasi dan komunikasi sistem men dukung identifikasi, perolehan, dan pertukaran informasi dalam bentuk dan kerangka waktu yang memungkinkan pegawai melaksanakan tanggung jawabnya. Informasi dan Komunikasi:

a) Informasi diidentifikasi, diperoleh, diolah dan dilaporkan

b) Komunikasi yang efektif Sistem informasi yang relevan terhadap tujuan pelaporan keuangan yang meliputi sistem akuntansi terdiri dari metoda dan catatan yang ditetapkan untuk mencatat, mengolah, mengikhtisarkan, dan melaporkan transaksi suatu entitas dan mempertahankan akuntabilitas untuk aktiva dan utang yang berkaitan. Komunikasi mencakup memberikan pemahaman peranan individual dan tanggung jawab yang berkaitan dengan pengendalian intern atas laporan keuangan. Komunikasi meliputi sejauh mana personel memahami bagaimana aktivitas mereka dalam sistem informasi pelaporan keuangan berkaitan dengan pekerjaan dan hal lainnya.

\section{5) Monitoring/Pengawasan}

Monitoring/pengawasan adalah suatu proses penilaian kualitas kinerja struktur pengendalian internal sepanjang waktu. Pengawasan menyangkut penilaian rancangan dan pelaksanaan operasi pengendalian oleh personil yang tepat untuk setiap periode waktu tertentu serta untuk menentukan bahwa Sistem Pengendalian Internal (SPI) telah berjalan sesuai dengan ketentuan maupun dilaksanakan modifikasi yang diperlukan karena adanya perubahanperubahan kondisi telah dilakukan. Pemantauan bisa terjadi atas aktifitas yang sedang berlangsung dan bisa juga dilakukan dengan evaluasi setiap akhir periode.

\subsection{Hubungan Antara Kompetensi, Pembinaan Karir Dan Kinerja Auditor}

Menurut Asikin (2006) seorang internal auditor dapat diukur kenerjanya melalui sikap profesionalisme, pengetahuan dan kecakapan,hubungan antar manusia dan komunikasi, pendidikan yang berkelanjutan dan kemampuan dalam menerapkan pengetahuan maupun penyerapan pengetahuan dalam mengikuti pelatihan di tempat kerja termasuk ketelitian professional yang diukur dari penerapan ketelitian dan kecakapan sehingga dalam pengungkapan temuan Auditnya dapat lebih dipertanggungjawabkan.

Wardoyo dan Lena (2010) mengungkapkan bahwa Peranan perusahaan dalam merekrut personil yang bertugas sebagai internal auditor mensyaratkan mempunyai pendidikan nonformal seperti memiliki Sertifakat CIA, dengan mensyaratkan tambahan pendidikan nonformal bagi internal auditor maka masalah kecurangan, kesalahan dan pelanggaran dalam pengelolaan perusahaan dapat ditekan karena berpedoman kepada kualitas pelaksanaan Good Corporate Governanc (GCG) yang nantinya secara cepat maupun secara lambat pelanggaran yang terjadi di manajemen dapat diperbaiki termasuk pentingnya standar Kode Etik Audit Internal karena bagi profesi audit internal, kode etik merupakan hal yang sangat penting dan diperlukan dalam pelaksanaan tugasnya secara profesional terutama yang menyangkut manajemen risiko, pengendalian dan proses tata kelola.Singgih dan Bawono (2010) berpandangan bahwa independensi, pengalaman.due professional care dan akuntabilitas secara simultan sangat berpengaruh terhadap kualitas Auditor. Wati, dkk (2010) menemukan bukti bahwa independensi, Gaya kepemimpinan, Komitmen organisasi dan pemahaman Good Governance berpengaruh positif terhadap kinerja Auditor.

Pratiwi dan Harmeidiyanti 
mengungkapkan bahwa secara simultan kecerdasan emosional, pengetahuan, Locus of Control, Independensi dan komunikasi berpengaruh signifikan terhadap kinerja pemeriksa internal Inspektorat. Bila dilihat secara parsial kecerdasan emosional, Locus of Control, Independensi berpengaruh signifikan
H1: Ada pengaruh kompetensi auditor terhadap kinerja auditor pada Inspektorat Jenderal dan PerbendaharaanInstansi Kementerian Pertahanan

H2: Ada pengaruh pembinaan karir terhadap kinerja auditor Inspektorat Jenderal dan Perbendaharaan Instansi Kementerian Pertahanan

\section{Gambar 1. Kerangka Pikir}

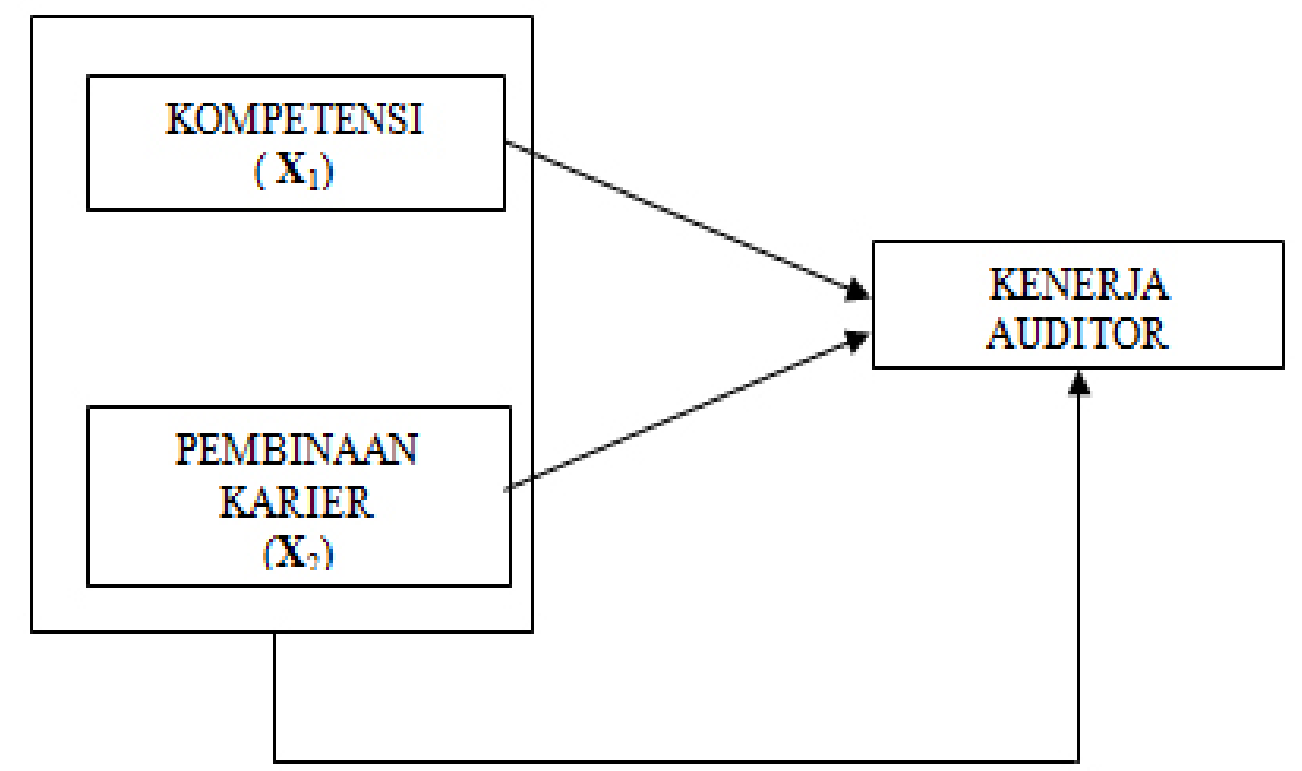

terhadap kinerja pemeriksa internal Inspektorat dan faktor yang paling dominan dari penelitian terhadap kinerja pemeriksa internal Inspektorat Kabupaten adalah kecerdasan emosional. Kisnawati (2012) menemukan bukti empiris bahwa bahwa secara simultan kompetensi, Independensi dan etika auditor berpengaruh signifikan terhadap kualitas audit.

Berdasarkan beberapa hasil penelitian tersebut dapat disimpulkan bahwa faktor pendidikan, pengalaman, independensi, pelatihan, etika auditor, pembinaan karier dan ketrampilan dalam melaksanakan audit sangat mempengaruhi terhadap efektifitas kinerja auditor sehingga faktor-faktor tersebut perlu mendapat perhatian untuk meningkatkan kualitas auditor di Inspektorat Pemerintah. Oleh karenanya hipotesis penelitian disusun sebagai berikut:

\section{Metode Penelitian}

Penelitian menggunakan metode survey. Sumber data berupa data primer yang dikumpulkan dengan cara menyebarkan kuesioner kepada seluruh pegawai di Inspektorat Jenderal dan Perbendaharaan Instansi Kementerian Pertahanan. Dari sejumlah 100 kuesioner yang disebarkan kepada responden, sejumlah 87 kuesioner terisi dengan lengkap dan diolah. pegawai pada di Inspektorat Jenderal dan Perbendaharaan Instansi Kementerian Pertahanan. Skala angka yang digunakan untuk variabel kompetensi, pembinaan karier dan kinerja auditor internal adalah interval yang dihasilkan dari suatu transformasi dari skala angka ordinal yang diperoleh dari instrumen penelitian untuk variabel $\mathrm{X}$ dan $\mathrm{Y}$. Angka ordinal untuk variabel $\mathrm{X}$ yaitu kompetensi dan pembinaan karier yang diperoleh dengan 
menggunakan Likert Summated Rating dimana responden diberi kuisioner dengan bobot tertinggi 5 dengan memilih angka 5 dan yang terendah adalah 1 bagi yang memilih angka 1 .

Definisi operasional dan pengukuranvariable mengacu pada definisi dan operasionalisasi variabel yang dapat dijelaskan sebagai berikut:

1. Variabel Independen : Kompetensi $\left(\mathrm{X}_{1}\right)$ Variabel kompetensi adalah untuk mengetahui kemampuan yang dimiliki oleh seorang auditor serta mempertahankan kemampuan itu sendiri, adapun dalam menilai variabel kompetensiyang dijadikan standart atau indikator penilaian adalah rekrutmen, keahlian khusus, pendidikan dan pengetahuan. pengukuran kompetensi mengacu pengukuran COSO (1992)

2. Variabel Independen : Pembinaan Karier $\left(\mathrm{X}_{2}\right)$

Variabel ini menggunakan standar yang telah dikeluarkan oleh BPKP (Badan Pengawasan Keuangan dan Pembangunan) maupun Peraturan Pemerintah nomor 60 tahun 2008 tentang Sistem Pengendalian Intern Pemerintah dan Buku Petunjuk Dasar Pengawasan dan Pemeriksaan TNI tahun 2006 , pola pembinaan dilaksanakan secara berlanjut berupa pemenuhan kebutuhan personil pemeriksa dan pembinaan personil APF (Aparat Pemeriksa Fungsional) sejalan dengan pembinaan personil instansi Kementerian Pertahanan serta berpedoman kepada peraturan dan perundang-undangan yang berlaku. Adapun variabel indikator yang digunakan meliputi : Pengalaman, Pengembangan Karier, Pendidikan dan Profesionalisme. Pengukuran pembinaan karir mengadopsi pengukuran yang dilakukan oleh Sawyer (2006)

3. Variabel Dependen : Kinerja Auditor (Y)

Variabel kinerja auditor internal merupakan efektifitas auditor internal dalam melakukan aktifitas audit internal. Indikator yang digunakan berdasarkan Standar Praktik Profesi Audit Internal yaitu Standar Kinerja Audit Internal (Seksi 2000) yang terdiri dari pengelolaan fungsi audit internal, lingkup perencanaan, manajemen sumber daya, kontrol, pelaksanaan penugasan, pengkomunikasian hasil penugasan dan pemantauan tindak lanjut. Indikator yang menjadi penilaian adalah Kualitas Audit, Motivasi, Independensi dan Tanggungjawab Auditor. Pengukuran kinerja auditor mengacu pada pengukuran yang dilakukan oleh Arens (2008)

Uji kualitas data dilakukan dengan uji validitas dan reliabilitas. Sugiyono (2011: 168) menyatakan bahwa instrumen yang valid berarti alat ukur yang digunakan untuk mendapatkan data (mengukur) itu valid. Kriteria yang digunakan untuk menentukan valid tidaknya alat test adalah dengan $\mathrm{df}=0,30, \dot{\alpha}=0,05$. dengan ketentuan sebagai berikut:

1. Uji validitas dinyatakan valid apabila nilai $r$ hitung dengan tingkat signifikan $\geq 0,05$ maka alat test dan apabila $\mathrm{r}_{\text {hitung }}$ dengan tingkat signifikan $<0,05$ maka dinyatakan tidak valid (drop). Secara statistik angka kolerasi yang diperoleh harus dibandingkan dengan angka kritis tabel kolerasi nilai $r$, teknik kolerasi yang digunakan adalah Product Moment (Sugiono, 2011,hal: 241)

2. Uji reliabilitas bertujuan untuk mengetahui apakah instrument yang digunakan dapat mengukur sesuatu yang diukur secara konsisten dari waktu ke waktu. Butir-butir indicator didinyatakan valid jika nilai Cronbach Alpha > 0.7 (Ghozali, 2007:).

Analisis data dilakukan dengan uji regresi berganda. Uji regresi dapat dikatakan sebagai pengujian model yang BLUE (Best, Linier, Unbiased, dan Estimated) jika terbebas dari penyakit asumsi klasik. Uji asumsi klasik dilakukan pada model penelitian mencakup:

1. Uji Mulitikolinearitas. Cara yang 
digunakan untuk mendeteksi ada tidaknya multikolinieritas adalah menggunakan Variace Inflation Factor (VIF). Jika nilai VIF nya kurang dari atau sama dengan 10 (Myer, 1990) maka dalam data tidak terdapat multikolinieritas.

2. Uji Heteroskedastisitas dilakukan untuk memberikan keyakinan bahwa data yang diuji adalah homogen. Jika terdapat hasil signifikan regresi sederhana variabel bebas terhadap nilai absolut dari residual (error) signifikan, maka dapat disimpulkan terhadap heteroskedastisitas (varians dari residual tidak homogen).

3. Uji Normalitas residual model dilakukan untuk menguji distribusi nilai residual model yang diuji. Model yang baik adalah jika distribusi residual modelnya lebih dari 0.05 pada $\alpha=5 \%$, dengan kata lain distribusi observasi dibandingkan distribusi teoritisnya tidak berbeda. Pengujian dapat juga dilakukan dengan menggunakan grafik p-plot. Jika data berada di sekitar sumbu diagomal maka dapat dikatakan normal.

Persamaan model penelitian digambarkan dalam persamaan regresi sebagai berikut:

$$
\mathrm{Y}=\mathrm{a}+\mathrm{b}_{1} \mathrm{X}_{1}+\mathrm{b}_{2} \mathrm{X}_{2}+\mathrm{e}
$$

Keterangan :

$$
\begin{aligned}
\mathrm{a}= & \text { nilai konstanta } \\
\mathrm{b}= & \text { nilai koefisien regersi variabel } \\
& \text { independen } \\
\mathrm{Y}= & \text { kinerja auditor } \\
\mathrm{X} 1= & \text { kompetensi } \\
\mathrm{X} 2= & \text { pembinaan karir } \\
\mathrm{e}= & \text { error }
\end{aligned}
$$

Pengujian model penelitian dilakukan dengan Uji Fisher (Uji F). Model yang baik adalah jika satu dari variable independen yang diuji berpengaruh terhadap variable dependennya. Model dikatakan baik jika signifikasi hasil uji $F<0,5$ pada $\alpha=5 \%$. Pengujian Hipotesis dilakukan dengan uji-t. Uji-t merupakan pengujian masing-masing variable independen terhadap dependen. Jika tingkat signifikansi hasil uji-t kurang dari 0,05 maka hipotesa yang didapat $\mathrm{H}_{1}$ dapat diterima dan $\mathrm{H}_{0}$ ditolak dan jika lebih dari atau sama dengan 0,05 maka hipotesa yang didapat $\mathrm{H}_{1}$ dapat ditolak dan hipotesa dari $\mathrm{H}_{0}$ diterima.

\section{Hasil Penelitian dan Pembahasan}

Responden yang digunakan dalam penelitian ini adalah seluruh pelaksana audit yang ada di Inspektorat Jenderal dan Perbendaharaan jajaran instansi Kementerian Pertahanan yaitu pejabat struktural dan fungsional dimana pejabat struktural dapat melaksanakan kegiatan pemeriksaan/ audit karena tugas dan tanggungjawabnya melaksanakan penempatan di Inspektorat yang seharusnya dibekali keahlian bidang audit. Dalam hal ini seseorang yang bertugas di Inspektorat akan dapat pemahaman atas segala kebutuhan serta kelemahan yang terjadi sehingga hambatan dapat diselesaikan dengan baik dan dilaksanakan lebih efektif, efisien dan ekonomis sesuai dengan aturan yang berlaku. Jumlah responden dalam penelitian sebanyak 87 responden dimana dari 100 kuisioner yang disebar. Dalam pengumpulan data adalah dengan pengiriman kuisioner secara langsung kepada para responden dengan jangka waktu pengisisn/ pengembalian kuisioner selama tujuh (7) hari kerja. Deskripsi dari variabel yang diuji adalah sebagai berikut:

Analisis statistik deskripsi bertujuan untuk memberikan gambaran umum dari data yang didapat yaitu mean, median, standar deviasi dan data minimum sesuai dengan tabel dibawah ini.

Magister Akuntansi Universitas Pancasila 
Tabel 1

Deskripsi Variabel

\begin{tabular}{lccc}
\hline & $\begin{array}{c}\text { Kompetensi } \\
(\mathbf{X 1})\end{array}$ & $\begin{array}{c}\text { Pembinaan Karier } \\
(\mathbf{X 2})\end{array}$ & $\begin{array}{c}\text { Kinerja Auditor } \\
(\mathbf{Y})\end{array}$ \\
\hline Mean & 47.67 & 63.86 & 70.99 \\
Median & 50.00 & 67.00 & 72.00 \\
Std. Deviation & 8.295 & 11.646 & 13.419 \\
Minimum & 13 & 17 & 18 \\
Maximum & 59 & 82 & 90 \\
\hline
\end{tabular}

Berdasarkandata daritabeldiataspeneliti menyatakan bahwa dari 87 sampel responden Kompetensi $\left(\mathrm{X}_{1}\right)$, Pembinaan Karier $\left(\mathrm{X}_{2}\right)$ dan Kinerja Auditor (Y) pada Inspektorat Jenderal dan Perbendaharaan yang diambil oleh peneliti terdapat rata-rata hitung/mean Kompetensi $\left(\mathrm{X}_{1}\right)$ sebesar 47.67, Pembinaan Karier $\left(\mathrm{X}_{2}\right)$ sebesar 63.86 dan Kinerja Auditor (Y) sebesar 70.99. Sedangkan nilai tengah/ median Kompetensi $\left(\mathrm{X}_{1}\right)$ sebesar 50.00, Pembinaan Karier $\left(\mathrm{X}_{2}\right)$ sebesar 67.00 dan Kinerja Auditor (Y) sebesar 72.00. Nilai standar deviasi untuk Kompetensi $\left(\mathrm{X}_{1}\right)$ sebesar 8.295, Pembinaan Karier $\left(\mathrm{X}_{2}\right)$ sebesar 11.646 dan Kinerja Auditor (Y) sebesar 13.419. Nilai minimum dari Kompetensi $\left(\mathrm{X}_{1}\right)$ sebesar 13, Pembinaan Karier $\left(\mathrm{X}_{2}\right)$ sebesar 17 dan Kinerja Auditor (Y) sebesar 18. Dari data yang didapat menunjukkan bahwa nlai Kompetensi $\left(\mathrm{X}_{1}\right)$, Pembinaan Karier $\left(\mathrm{X}_{2}\right)$ dan Kinerja Auditor (Y) bervariasi.

Hasil uji kualitas data yang mencakup uji validitas dan reliabilitas terangkum pada Tabel 2, dimana dari 13 indikator variabel kompetensi, 17 indikator variabel pembianaan karir, 18 indikator kinerja auditor, semuanya terbukti mampu menjadi pengukur variabel, atau dapat dikatakan valid. Indikator-indikator pengkur untuk tiga variabel yang diuji juga terbukti reliabel. Rangkuman hasul pengujian sebagaimana tampak pada Tabel 2.

\section{Hasil uji validitas dan reliabilitas dapat dirangkum pada tabel berikut:}

\begin{tabular}{llccc}
\hline No & Variabel & $\begin{array}{c}\text { Jumlah } \\
\text { Indikator }\end{array}$ & $\begin{array}{c}\text { Hasil } \\
\text { Uji } \\
\text { validitas }\end{array}$ & $\begin{array}{c}\text { Hasil uji } \\
\text { Reliabilitas }\end{array}$ \\
\hline 1 & Kompetensi & 13 & $\begin{array}{l}\text { Valid pada } \\
\text { r hitung }>\end{array}$ & 0,887 \\
2 & Pembinaan karir & 17 & 0,941 \\
3 & Kinerja Auditor & 18 & 0,40 & 0,967 \\
\hline
\end{tabular}

Hasil uji asumsi klasik, menunjukkan bukti bahwa distribusi nilai residual berada pada sumbu diagonal berdasarkan grafik p-plot. Berdasarkan perhitungan bahwa angka tolerance dari variabel independen kompetensi dan independensi mempunyai nilai tolerance lebih dari 0,10 berarti bahwa tidak ada korelasi antar variabel indpenden yang nilainya lebih dari 95\%. Sementara itu, hasil perhitungan nilai Variance Inflantion Factor (VIF) juga menunjukkan hal yang sama. Tidak ada satupun variabel independen yang memiliki nilai VIF lebih dari 10 dan dapat disimpulkan tidak terjadi multikolinieritas antar variabel independen tersebut. Hasil uji heteroskedastisitas menunjukkan tidak ditemukan pola tertentu yang jelas, serta titiktitik tersebar di atas dan di bawah angka 0 pada sumbu Y, maka mengindikasikan tidak terjadi heteroskedastisitas.

Hasil uji regresi menunjukkan bahwa model yang diuji dan tercermin dari hasil Uji F menunjukkan bahwa $\mathrm{F}_{\text {hitung }}$ untuk model yang diperoleh sebesar : 251,005 dengan tingkat 
signifikan 0,000 maka model regresi bisa dipakai untuk memprediksi Kinerja Auditor (Y) atau dapat dikatakan bahwa Kompetensi Auditor $\left(\mathrm{X}_{1}\right)$ dan Pembinaan Karier $\left(\mathrm{X}_{2}\right)$ secara bersamaan mempengaruhi Kinerja Auditor (Y). Hal ini menunjukkan bahwa model yang diuji merupkan model yang baik.

Tujuan pengujian hipotesis adalah untuk mendapatkan kesimpulan apakah hipotesis penelitian yang dirumuskan telah sesuai atau tidak dengan data yang diperoleh, maka hipotesis yng diuji adalah hasil hipotesis statistik yang dinyatakan dalam bentuk hipotesis nol $\left(\mathrm{H}_{0}\right)$. Sebelum digunakan sebagai dasar kesimpulan pengujian hipotesis dilakukan dengan menggunakan statistik dan data yang ada diuji secara simultan dan parsial untuk melihat apakah model yang didapat dan koefisien regresinya dapat dikatakan bermakna secara statistik dan dapat diambil kesimpulan secara umum mengenai pengaruh kompetensi dan pembinaan karier terhadap kinerja auditor. Berikut adalah hasil Uji-t. sebesar 0,317 artinya jika variabel Pembinaan Karier $\left(\mathrm{X}_{2}\right)$ konstan maka peningkatan Kompetensi $\left(\mathrm{X}_{1}\right)$ satu satuan akan meningkatkan Kinerja Auditor (Y) sebesar 0,317 dan koefisien regresi Pembinaan Karier $\left(\mathrm{X}_{2}\right)$ sebesar 0,866 maka artinya jika variabel Kompetensi $\left(\mathrm{X}_{1}\right)$ konstan maka peningkatan Kinerja Auditor (Y) sebesar 0,866 satuan.

Dari penggolaan statistik jika tingkat signifikansi kurang dari 0,05 maka hipotesa yang didapat $\mathrm{H}_{1}$ dapat diterima dan hipotesa dari $\mathrm{H}_{0}$ ditolak. Namun bila tingkat signifikansi lebih dari 0,05 maka hipotesa yang didapat $\mathrm{H}_{1}$ dapat ditolak dan hipotesa dari $\mathrm{H}_{0}$ diterima. Dari hasil pengujian $\mathrm{F}_{\text {hitung }}$ dan $\mathrm{R}$ menunjukkan bahwa Kompetensi $\left(\mathrm{X}_{1}\right)$ dan Pembinaan Karier $\left(\mathrm{X}_{2}\right)$ berpengaruh signifikan terhadap Kinerja Auditor (Y). Untuk menghasilkan kinerja auditor yang baik diperlukan suatu standar dan pedoman pelaksanaan audit internal agar profesionalisme auditor dapat terjaga. Salah satu dari standar yang ada untuk internal auditor

Tabel 2

Hasil Uji Hipotesis

Coefficients $^{\text {a }}$

\begin{tabular}{|c|c|c|c|c|c|c|c|c|}
\hline & \multirow{2}{*}{ Model } & \multicolumn{2}{|c|}{$\begin{array}{l}\text { Unstandardized } \\
\text { Coefficients }\end{array}$} & \multicolumn{2}{|c|}{$\begin{array}{c}\text { Standardized } \\
\text { Coefficients }\end{array}$} & \multirow[b]{2}{*}{ Sig. } & \multicolumn{2}{|c|}{$\begin{array}{l}\text { Collinearity } \\
\text { Statistics }\end{array}$} \\
\hline & & B & $\begin{array}{l}\text { Std. } \\
\text { Error }\end{array}$ & Beta & $\mathbf{t}$ & & $\begin{array}{c}\text { Tolerance } \\
\text { e }\end{array}$ & VIF \\
\hline \multirow{3}{*}{1} & (Constant) & .562 & 3.286 & & .171 & .865 & & \\
\hline & Kompetensi & .317 & .131 & .196 & 2.428 & .017 & .262 & 3.817 \\
\hline & Pembinaan Karir & .866 & .093 & .752 & 9.316 & .000 & .262 & 3.817 \\
\hline
\end{tabular}

a. Dependent Variable: Kinerja Auditor

Sumber: Hasil pengolahan data SPSS

Dari hasil perhitungan regresi berganda linier maka persamaan regresinya adalah :

$$
\mathrm{Y}=0,562+0,317 \mathrm{X}_{1}+0,866 \mathrm{X}_{2}+\varepsilon
$$

Dari hasil perhitungan. Jika nilai intercept (a) sebesar 0,562 artinya jika Kompetensi $\left(\mathrm{X}_{1}\right)$ dan Pembinaan Karier $\left(\mathrm{X}_{2}\right)$ sama-sama nol, maka Kinerja Auditor (Y) sebesar 0,562 satuan. Koefisien regresi parsial Kompetensi $\left(\mathrm{X}_{1}\right)$ pemerintah mengacu pada Standar Kompetensi Auditor yang dikeluarkan oleh Badan Pengawasan Keuangan dan Pembangunan maupun dari konsorsium Organisasi Profesi Audit Internal.

\section{Simpulan, Keterbatasan, dan Implikasi Hasil Penelitian}


Berdasarkan hasil dari penelitian yang dilaksanakan dan pembahasan maka dapat disimpulkan sebagai berikut :

a. Kompetensi dan pembinaan karier auditor secara simultan berpengaruh nyata atau signifikan terhadap kinerja auditor internal di jajaran Inspektorat Jenderal dan Perbendaharaan instansi Kementerian Pertahanan, karena kinerja auditor sendiri hasilnya karena pengaruh yang didapat dari kompetensi dan pembinaan karier auditor itu sendiri.

b. Dari hasil uji secara parsial maka didapat bahwa kompetensi dan pembinaan karier auditor di jajaran instansi Kementerian Pertahanan berpengaruh positif dan signifikan terhadap kinerja auditor.

c. Standar Kompetensi Auditor yang dikeluarkan oleh Badan Pengawasan Keuangan dan Pembangunan selaku badan yang membina auditor di jajaran instansi pemerintah perlu dijadikan pedoman dalam pelaksanaan kompetensi dan pembinaan karier auditor di jajaran instansi Kementerian Pertahanan, oleh karena itu maka pimpinan Inspektorat di jajaran instansi Kementerian Pertahanan dalam perekrutan auditor harus didasarkan oleh latar belakang pendidikan serta kemampuan kompetensi teknis yang memadai untuk mendukung pelaksanaan tugas yang diberikan kepada seorang auditor.

d. Dalam mempertahankan kompetensi seorang auditor agar bekerja secara profesional diperlukan suatu pengembangan pengetahuan, maupun pendidikan yang sangat menunjang pelaksanaan audit sedangkan untuk pembinaan kariernya harus tertata dengan baik dan jelas serta dilaksanakan sesuai dengan persyaratan yang berlaku. Sehingga seorang audit internal dapat bekerja secara profesional dengan didukung oleh kemampuan intelektual serta tanggungjawab yang dibebankan kepadanya merupakan bekal utama yang sangat bernilai untuk mendapatkan kinerja yang memuaskan.

Implikasi hasil penelitian dalam rangka peningkatkan kinerja auditor internal di Inspektorat Jenderal dan Perbendaharaan jajaran instansi Kementerian Pertahanan dapat penulis sampaikan beberapa saran yang berhubungan dengan hasil penelitian diantaranya adalah :

a. Dalam perekrutan personil yang menjadi pengawak Inspektorat perlu kiranya diperhatikan latar belakangnya mulai dari aspek psikologi serta kemampuan dan keahlian yang dapat mempengaruhi lingkungan Inspektorat jajaran instansi Kementerian Pertahanan serta perlu dibuat organisasi tersendiri di bawah Inspektorat yang berlaku untuk pembinaan auditor di seluruh jajaran instansi Kementerian Pertahanan.

b. Perlu segera direalisasikan pembentukan forum komunikasi Aparat Pemeriksa Fungsional di lingkungan Dephan dan instansi Kementerian Pertahanan yang dapat digunakan sebagai media pertukaran informasi, koordinasi dan sosialisasi berbagai aturan dan perundangundangan baru yang berkaitan dengan tugas lembaga Inspektorat. Keberadaan forum ini dirasakan penting guna mengantisipasi dan memecahkan berbagai persoalan yang mungkin timbul dan menghambat penyelenggaraan fungsi pengawasan dan pemeriksaan.

c. Itjen instansi Kementerian Pertahanan selakubadanpembinaauditorseluruhjajaran instansi Kementerian Pertahanan perlu membuatstandartkompetensiAuditoruntuk jajaran instansi Kementerian Pertahanan agar kegiatan audit dapat dilaksanakan secara profesional, independen, terarah dan obyektif berdasarkan kode etik dan standar pemeriksaan yang baku maka perlu dilaksanakan pelatihan setiap tahun sesuai dengan aturan maksimal 80 jam pelajaran dan wajib diikuti oleh seluruh auditor di jajaran instansi Kementerian Pertahanan.

d. Untuk memenuhi tuntutan masyarakat 
akan transparansi dan akuntabilitas tugastugas pemerintahan, Kemhan dan instansi KementerianPertahananperlumerumuskan kembali suatu Sistem Akuntansi seperti yang telah diamanatkan dalam Peraturan Pemerintah nomor 24 Tahun 2005 tentang Standar Akuntansi Pemerintahan dan Kemhan harus dapat merubah sistem pencatatan dan pelaporan yang digunakan saat ini disesuai dengan perkembangan organisasi karena masih kelemahan dalam sistem akuntansi yang digunakan oleh Kemhan dan instansi Kementerian Pertahanan. Dalam pelaksanaan kegiatan diharapkan punish dan reward dapat diterapkan sesuai dengan ketentuan yang berlaku.

\section{Daftar Pustaka}

Agoes Sukrisno, Auditing Petunjuk Praktis Pemeriksaan Akuntan oleh Akuntan Publik Edisi 4, Jakarta, Salemba Empat, 2012.

Al Haryono Jusuf. 2001. Dasar-Dasar Akuntansi Jilid 2. Yogyakarta: STIE YKPN.

Anthony, R. dan V. Govindarajan. 2005. Sistem Pengendalian Manajemen (Terjemahan). Jakarta: Salemba Empat.

Arens dkk, Auditing dan Jasa Assurance Edisi 12, Jakarta, Penerbit Erlangga, 2008

Arikunto Suharsimi, Prosedur Penelitian Suatu Pendekatan Praktek, Yogyakarta,PT Rineka Cipta: 2010.

Asikin, Zainal dkk. 2006. Dasar-dasar Hukum

Perburuhan. Jakarta: PT Raja Grafindo

Persada.

Bawono, Singgih, 2010. "Faktor-Faktor dalam

Diri Auditor dan Kualitas Audit: Studi Pada KAP Big four di Indonesia”. Skripsi. Jurusan Akuntansi. UNSOED.Purwokerto

BPK RI, Pemeriksaan Pengelolan dan Tanggungjawab Keuangan Negara, UU RI nomor 15, Jakarta, 2004.

BPK RI, Peraturan Badan Pemeriksa Keuangan

Republik Indonesia nomor 01 Tahun 2007

Tentang Standar Pemeriksaan Keuangan

Negara,Jakarta:Kementerian HAM
Republik Indonesia,2007.

BPK RI, Peraturan Badan Pemeriksa Keuangan

Republik Indonesia nomor 02 Tahun 2007

Tentang Kode Etik Badan Pemeriksa

Keuangan,Jakarta:Kementerian HAM

Republik Indonesia,2007.

BPK RI, Undang-Undang RI nomor 15 Tentang

Badan Pemeriksa Keuangan,Jakarta:

Kementerian HAM Republik

Indonesia,2006.

Buku Petunjuk Dasar Pengawasan dan Pemeriksaan Tentara Nasional Indonesia, sesuai Surat Keputusan Panglima TNI nomor: SKEP/221/VI/2006 tanggal 14 Juni 2006,Jakarta,Setum Mabes TNI.

Buku Petunjuk Induk Pengawasan dan Pemeriksaan TNI sesuai Surat Keputusan Panglima TNI nomor: SKEP/25/I/2013 tanggal 17 Januari 2013,Jakarta,Setum Mabes TNI.

Ghozali, Imam. 2007. Aplikasi Analisis Multivariate dengan Program SPSS.

Semarang: Badan Penerbit Universitas Diponegoro.

Gomes, Faustino Cardoso, 2003, Manajemen Sumber Daya Manusia, Penerbit Andi, Yogyakarta.

Jensen, M. C and Meckling, W.H. 1976. Theory of the Firm : Managerial Behavior,

Agency Costs and Ownership Structure. Journal of Financial Economics,

Oktober, 1976, V. 3, No. 4, pp. 305-360. Avalaible from: http://papers.ssrn.com

Jusup AI. Haryono, Auditing Cetakan Pertama,Yogyakarta, Sekolah Tinggi Ilmu Ekonomi YKPN: 2001.

Kisnawati, Baiq. 2012. Pengaruh Kompetensi, Independensi dan Etika Auditor Terhadap Kualitas Audit (Studi Empiris Pada Auditor Pemerintah di Inspektorat Kabupaten dan Kota Se-Pulau Lombok).Jurnal Bisnis dan Kewirausahaan. Vol.8. No.3. Nopember 2012

Konsorsium Organisasi Profesi Auditor Internal ,Standar Porfesi Audit Internal,Jakarta,2004.

Myers, R. H. (1990), Classical and Modern 
Regression with Application, 2nded.,

Peraturan Menteri Pendayagunaan Aparatur

Negara Nomor PER/220/M.PAN/7/2008

Tahun 2008 Tentang Jabatan Fungsional

Auditor Dan Angka Kreditnya, Kementerian PAN, Jakarta,2008.

Peraturan Menteri Pertahanan Republik

Indonesia Nomor 21 Tahun 2010 Tentang

Sistem Pengendalian Intern Di Lingkungan

Kementerian Pertahanan Dan Tentara

Nasional Indonesia, Jakarta: Kementerian

HAM Republik Indonesia,2010.

Peraturan Pemeritah Republik Indonesia Nomor

60 Tgl 28 Agustus 2008 Tentang Sistem

Pengendalian Intern Pemerintah,Jakarta:

Sekretariat Negara,2008.

Peraturan Presiden Republik Indonesia No. 94

Tahun 2006 Tentang Kedudukan, Tugas,

Fungsi, Susunan Organisasi Dan Tata Kerja

Kementerian Negara Republik Indonesia,

Jakarta,2006.

Peraturan Presiden Republik Indonesia Nomor

24 Tahun 2010 Tentang Kedudukan, Tugas,

Dan Fungsi Kementerian Negara Serta

Susunan Organisasi, Tugas, Dan Fungsi

Eselon I Kementerian Negara,Jakarta

: Sekretaris Kabinet Republik

Indonesia,2010.

Peraturan Presiden Republik Indonesia Nomor

47 Tahun 2009 Tentang Pembentukan

Dan Organisasi Kementerian Negara,

Jakarta : Sekretaris Kabinet Republik

Indonesia,2009.

Peraturan Presiden Republik Indonesia Nomor

9 Tahun 2005 Tentang Kedudukan,

Tugas, Fungsi,Susunan Organisasi, Dan

Tata Kerja Kementerian Negara Republik Indonesia,Jakarta,2005.

Pratiwi, Umi dan Harmeidiyanti, Sri, 2013, Analisis Faktor-FaktorYang Mempengaruhi

Kinerja Pemeriksa Internal Inspektorat di Wilayah Kabupaten Banyumas, Jurnal. usm.ac.id/elibs/USM_cd2b9.

Sawyer Lawrence B. dkk, Audit Internal Sawyer Edisi 5, Jakarta, Salemba Empat, 2006.

Sugiono, Metode Penelitian

Kombinasi,Bandung:Alfabeta: 2011.
Undang-Undang Dasar 1945, Jakarta: Sekretaris Negara Republik Indonesia, 1945.

Undang-Undang RI Nomor 13 Thn 2003 ttg K etenagakerjaan,Jakarta,Sekretaris Negara Republik Indonesia: 2003.

Wati, Elya. 2010. Pengaruh Idepedensi, Gaya Kepemimpinan, Komitmen Organisasi, dan

Pemahaman Good Governance Terhadap Kinerja Auditor Pemerintah. Universitas Bengkulu. 